\title{
Bright and Efficient, Non-Doped, Phosphorescent Organic Red-Light-Emitting Diodes**
}

\author{
By Yi-Hwa Song, Shi-Jay Yeh, Chin-Ti Chen,* Yun Chi,* Chao-Shiuan Liu, Jen-Kan Yu, Ya-Hui Hu, \\ Pi-Tai Chou,* Shie-Ming Peng, and Gene-Hsiang Lee
}

$\mathrm{Ir}^{(\mathrm{III})}$ metal complexes with formula $\left[(\text { nazo })_{2} \operatorname{Ir}(\mathrm{Fppz})\right](\mathbf{1}),\left[(\text { nazo })_{2} \operatorname{Ir}(\mathrm{Bppz})\right](\mathbf{2})$, and $\left[(\text { nazo })_{2} \operatorname{Ir}(\mathrm{Fptz})\right](\mathbf{3})[($ nazo $) \mathrm{H}=4$-phenyl quinazoline, (Fppz)H =3-trifluoromethyl-5-(2-pyridyl) pyrazole, $(\mathrm{Bppz}) \mathrm{H}=3$-t-butyl-5-(2-pyridyl) pyrazole, and $(\mathrm{Fptz}) \mathrm{H}=3$ trifluoromethyl-5-(2-pyridyl) triazole] were synthesized, among which the exact configuration of $\mathbf{1}$ was confirmed using singlecrystal X-ray diffraction analysis. These complexes exhibited bright red phosphorescence with relatively short lifetimes of 0.4$1.05 \mu \mathrm{s}$ in both solution and the solid-state at room temperature. Non-doped organic light-emitting diodes (OLEDs) were fabricated using complexes $\mathbf{1}$ and $\mathbf{2}$ in the absence of a host matrix. Saturated red electroluminescence was observed at $\lambda_{\max }=626 \mathrm{~nm}$ (host-emitter complex 1) and $652 \mathrm{~nm}$ (host-emitter complex 2), which corresponds to coordinates $(0.66,0.34)$ and $(0.69,0.31)$, respectively, on the 1931 Commission Internationale de l'Eclairage (CIE) chromaticity diagram. The nondoped devices employing complex 1 showed electroluminance as high as $5780 \mathrm{~cd} \mathrm{~m}^{-2}$, an external quantum efficiency of $5.5 \%$ at $8 \mathrm{~V}$, and a current density of $20 \mathrm{~mA} \mathrm{~cm}^{-2}$. The short phosphorescence lifetime of $\mathbf{1}$ in the solid state, coupled with its modest $\pi-\pi$ stacking interactions, appear to be the determining factors for its unusual success as a non-doped host-emitter.

\section{Introduction}

Iridium metal complexes containing the 2-phenyl pyridine (ppy) type of chelating ligands have attracted much attention in recent years. ${ }^{[1]}$ Preparing organic light-emitting devices (OLEDs) using emitters such as $\operatorname{Ir}(\mathrm{ppy})_{3}$ and its derivatives, in which a strong spin-orbit coupling is induced by the heavy Ir $^{\mathrm{III}}$ metal atom, effectively promotes intersystem crossing and provides OLEDs with unprecedented electroluminescence (EL) efficiencies since both singlet and triplet excitons can decay radiatively. ${ }^{[2]}$ Moreover, wavelength tunability over the entire visible spectrum has been achieved via systematically designing ancillary groups on the cyclometallated ligands. ${ }^{[3]}$ As would be expected, success in the development of these light-emitting materials is essential for the realization of an efficient, full-color OLED display.

In order to optimize device efficiency up to a theoretical limit, it these heavy metal complex emitters have been doped into

[*] Dr. C.-T. Chen, S.-J. Yeh

Institute of Chemistry, Academia Sinica

Taipei, 11529 (Taiwan, ROC)

E-mail: cchen@chem.sinica.edu.tw

Prof. Y. Chi, Y.-H. Song, Prof. C.-S. Liu

Department of Chemistry, National Tsing Hua University

Hsinchu, 300 (Taiwan, ROC)

E-mail: ychi@mx.nthu.edu.tw

Prof. P.-T. Chou, J.-K. Yu, Y.-H. Hu, Prof. S.-M. Peng, G.-H. Lee

Department of Chemistry and Instrumentation Center

National Taiwan University

Taipei, 106 (Taiwan, ROC)

E-mail: chop@ntu.edu.tw

[***] This work was supported by the National Science Council of the Republic of China. We thank Prof. Yu-Tai Tao for instruction in the fabrication and measurement of OLEDs. a layer of charge-transporting host material comprised of $4,4^{\prime}-N, N^{\prime}$-dicarbazole-biphenyl (CBP) or another host. ${ }^{[4]}$ The remarkable enhancement in efficiency upon doping CBP was ascribed to its bipolar carrier transport, along with a favorable triplet energy level alignment between the host material and the $\mathrm{Ir}^{\mathrm{III}}$ dopant, resulting in an increase of the energy-transfer efficiency. In addition, triplet-triplet (T-T) annihilation, which is a key adverse factor for phosphorescence-based emitters, can also be greatly inhibited by dispersing emitter molecules into the host matrix. This method has become a standard protocol for phosphorescent emitters. In contrast, high-performance phosphorescent OLEDs fabricated by a much simplified, non-doped method are rare and are mostly limited to short-wavelength (blue to yellow) emitters. ${ }^{[5,6]}$ Long-wavelength orange or red OLEDs fabricated with non-doped, phosphorescent host-emitters are rare and their typical performances are far from satisfactory. ${ }^{[6]}$ Compared with doped phosphorescent OLEDs, their non-doped counterparts are neither bright in peak radiance $\left(<1000 \mathrm{~cd} \mathrm{~m}^{-2}\right.$ for orange and $<380 \mathrm{~cd} \mathrm{~m}^{-2}$ for red devices) nor effective in peak efficiency ( $<3.5 \mathrm{~cd} \mathrm{~A}^{-1}$ for orange and $<2.3 \mathrm{~cd} \mathrm{~A}^{-1}$ for red devices). ${ }^{[6]}$ Studies have also revealed that most of the red fluorescence emitters are composed of an extensively conjugated aromatic $\pi$-system, and hence should have a higher tendency to form a microcrystalline aggregate, resulting in rapid fluorescence quenching due to enhanced dipole-dipole interactions and/or $\pi-\pi$ stacking interactions. ${ }^{[7]}$ In this context, there should also be hardly any exceptions for the phosphorescent emitters. Herein, we report a new series of Ir $^{\mathrm{III}}$ complexes, with coordination spheres consisting of two chelating phenyl substituted quinazoline and one (2-pyridyl) pyrazolate entity, which prove to serve as promising, non-doped, red phosphorescent hostemitters with relatively high efficiencies. Comprehensive structural characterization and photophysical properties have also 
been conducted in an attempt to unveil the key factors in the success of this unconventional phosphorescent host-emitter.

\section{Results and Discussion}

\subsection{Synthesis}

A synthetic pathway leading to the desired Ir complexes is depicted in Scheme 1. First of all, a 4-phenyl substituted quinazoline ligand, (nazo)H, was obtained from the condensation reaction of 2-aminobenzophenone and formamide, according to the literature method. ${ }^{[8]}$ The subsequent reaction of the (nazo) $\mathrm{H}$ ligand with $\mathrm{IrCl}_{3} \cdot n \mathrm{H}_{2} \mathrm{O}$ in refluxing methoxyethanol
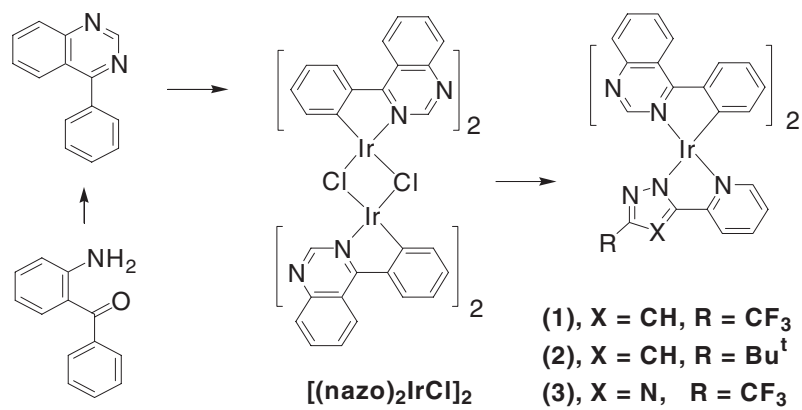

(1), $\mathrm{X}=\mathrm{CH}, \mathrm{R}=\mathrm{CF}_{3}$

(2), $\mathrm{X}=\mathrm{CH}, \mathrm{R}=\mathrm{Bu}^{\mathrm{t}}$

(3), $\mathrm{X}=\mathrm{N}, \quad \mathrm{R}=\mathrm{CF}_{3}$

Scheme 1. Synthetic method leading to desired complexes.

afforded the chloride-bridged dimer complex $\left[(\text { nazo })_{2} \operatorname{IrCl}\right]_{2}$ in a high yield. This dimer complex reacted easily with the pyrazole or triazole ligand to afford the emissive monomeric complexes of formula [(nazo $\left.)_{2} \operatorname{Ir}(\mathrm{Fppz})\right](\mathbf{1}),\left[(\mathrm{nazo})_{2} \operatorname{Ir}(\mathrm{Bppz})\right](\mathbf{2})$, and $\left[(\text { nazo })_{2} \operatorname{Ir}(\mathrm{Fptz})\right](\mathbf{3})$, in the presence of $\mathrm{Na}_{2} \mathrm{CO}_{3}$, where $(\mathrm{Fppz}) \mathrm{H}=3$-trifluoromethyl-5-(2-pyridyl) pyrazole, $(\mathrm{Bppz}) \mathrm{H}=$ 3-t-butyl-5-(2-pyridyl) pyrazole, and (Fptz) $\mathrm{H}=3$-trifluoromethyl-5-(2-pyridyl) triazole. These complexes were then characterized using routine methods. Complex 1 was further examined using single-crystal $\mathrm{X}$-ray diffraction analysis to establish its exact configuration.

\subsection{X-ray Crystal Structure}

Complex 1, which consists of two cyclometallated phenyl quinazoline fragments and one (2-pyridyl) pyrazolate ligand has a distorted octahedral geometry around the iridium atom, as depicted in Figure 1. The cyclometallated phenyl quinazoline ligands adopt an eclipsed orientation, and its spatial arrangement is akin to that observed for the chloride-bridged dimer complex $\left[(\text { ppy })_{2} \operatorname{Ir}(\mu-\mathrm{Cl})\right]_{2}{ }_{2}^{[9]}$ and monomeric acetylacetonate (acac) complexes such as $(\mathrm{ppy})_{2} \operatorname{Ir}(\mathrm{acac}) .^{[10]}$ The pyrazolate chelate is located opposite to the cis-oriented carbon atoms, completing an octahedral arrangement. The quinazoline core skeleton

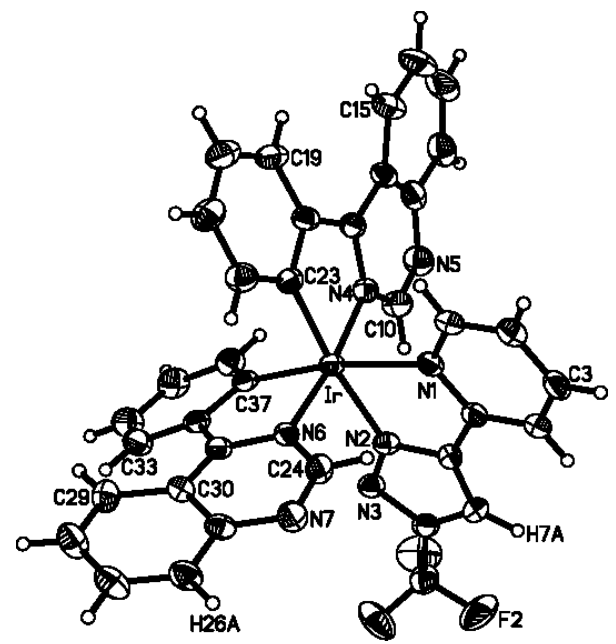

Figure 1. ORTEP diagram of 1. Selected bond distances $[\AA \AA A]$ : Ir$\mathrm{N}(1)=2.164(4), \operatorname{Ir}-\mathrm{N}(2)=2.105(4), \operatorname{Ir}-\mathrm{N}(4)=2.041(4), \operatorname{Ir}-\mathrm{N}(6)=2.040(4)$, $\operatorname{Ir}-\mathrm{C}(23)=2.007(5), \operatorname{Ir}-\mathrm{C}(37)=1.996(5) \AA$ and angles [degrees]: $\mathrm{N}(1)-\mathrm{Ir}-$ $N(2)=76.5(2), N(4)-\operatorname{Ir}-C(23)=79.1(2), N(6)-\operatorname{Ir}-C(37)=79.6(2)$.

shows a large deformation with respect to the adjacent 4-phenyl substituent, for which the calculated plane-to-plane dihedral angles are 23.9/ and 29.4/. Obviously, this distortion is due to an unfavorable steric hindrance originating from the through-space repulsion between the two nearby ortho-hydrogen atoms on C(15) and C(19) as well as on C(29) and C(33). A similar structure has been observed in the related isoquinoline system. ${ }^{[11]}$ Nevertheless, the intermolecular packing diagram of 1 reveals several weak but notable intermolecular interactions (see Fig. 2) that possibly play a role in the radiationless quenching of the phosphorescent emission. First of all, one of the quinazoline ligands is nearly parallel to the pyridyl ring of the neighboring molecule. This is clearly shown by the rather short non-bonding contact of $3.31 \AA$ between the $\mathrm{C}(3)$ atom of the unique pyridyl-pyrazolate ligand and the $\mathrm{C}(30)$ atom of the quinazoline ligand of the adjacent molecule (see Figs. 1 and 2 for atom labeling).

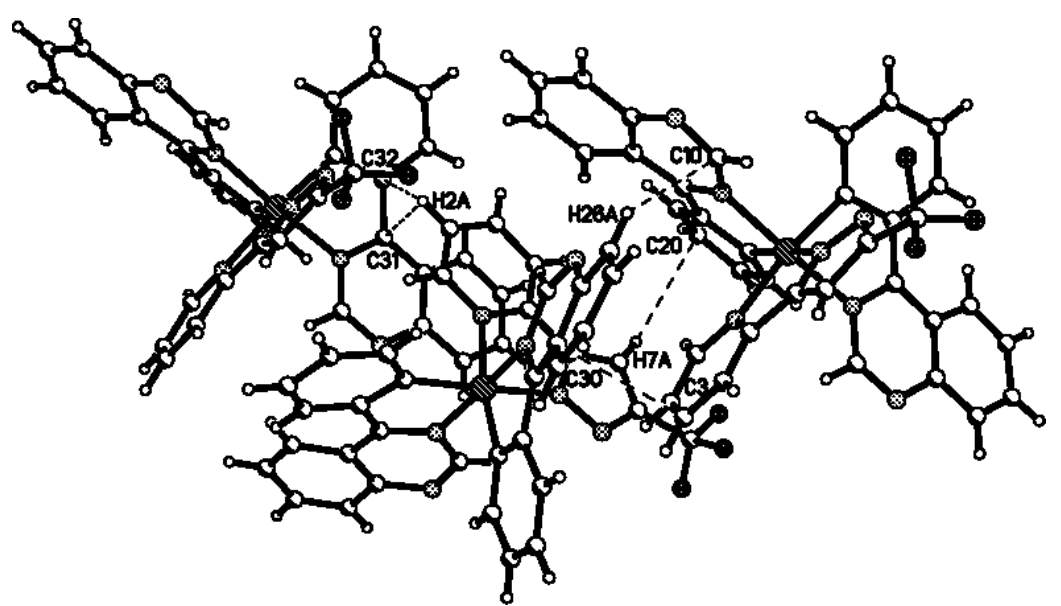

Figure 2. Portion of the crystal-packing diagram of 1 . The weak intermolecular non-bonding contacts are marked with dotted lines. 
The second class of interaction may be attributed to the edge-to-face ring contact (3.09 $\AA$ ) between the $\mathrm{H}(26 \mathrm{~A})$ atom of one quinazoline ligand and the $\mathrm{C}(10)$ atom of the pyridylpyrazolate ligand of the adjacent molecule (Fig. 2). Similar short contacts $(\mathrm{H}(2 \mathrm{~A}) \cdots \mathrm{C}(31)=3.10 \AA, \mathrm{H}(2 \mathrm{~A}) \cdots \mathrm{C}(32)=3.08 \AA$, and $\mathrm{H}(7 \mathrm{~A}) \cdots \mathrm{C}(20)=3.03 \AA$ ) were also found between the $\mathrm{H}(2 \mathrm{~A})$ and $\mathrm{H}(7 \mathrm{~A})$ atoms of the pyridyl-pyrazolate ligand and the adjacent phenyl quinazoline ligand. However, such intermolecular interactions are unlikely to enhance the unwanted triplet-triplet annihilation, as the energy level of the pyrazolate fragment is too high to interfere with the normal emission from the ${ }^{3}$ MLCT or the corresponding ${ }^{3} \pi-\pi^{*}$ state localized on the quinazoline ligand. ${ }^{[12]}$ All together, a detailed structural analysis shows a moderate $\pi-\pi$ stacking for $\mathbf{1}$ in the crystal, which is expected to have an adverse effect for making a host-emitter. In contrast, however, a highly efficient host-emitter has been fabricated for $\mathbf{1}$, indicating that other factors must predominate in the device performance (see below).

\subsection{Photophysical Characterization of the Phosphorescence}

Figure 3 shows the UV-vis absorption and emission spectra of complexes 1-3 in $\mathrm{CH}_{2} \mathrm{Cl}_{2}$ at $298 \mathrm{~K}$. All three complexes possess similar spectral features, in which the two lower-lying

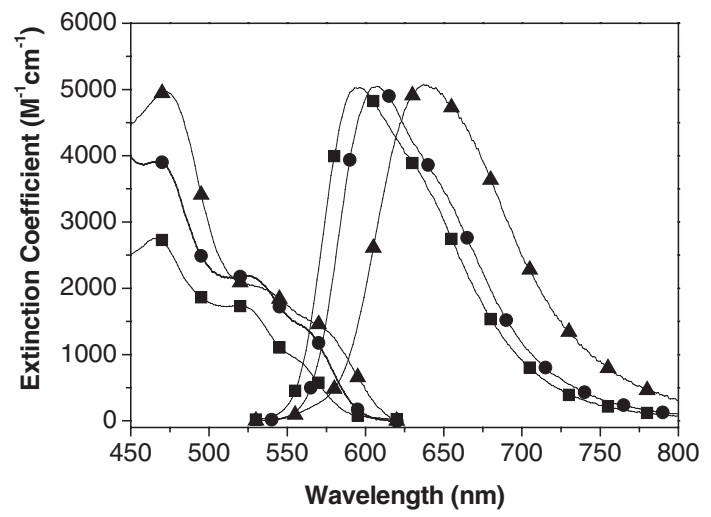

Figure 3. UV-vis absorption and normalized emission spectra of $\mathbf{1}(\mathbf{0}), \mathbf{2}$ $(\boldsymbol{\Delta})$, and $3(\boldsymbol{\square})$ in $\mathrm{CH}_{2} \mathrm{Cl}_{2}$ at $298 \mathrm{~K}$. Note that the emission spectra were acquired under degassed conditions.

bands that appear in the region of $\approx 500-625 \mathrm{~nm}$, as supported by their extinction coefficients of $\leq 3000 \mathrm{M}^{-1} \mathrm{~cm}^{-1}$, are tentatively assigned to the ${ }^{1} \mathrm{MLCT}$ and ${ }^{3} \mathrm{MLCT}$ transitions. The close absorptivity between these two bands, e.g., $\varepsilon=2150$ and $1330 \mathrm{M}^{-1} \mathrm{~cm}^{-1}$ at peak wavelengths of 525 and $565 \mathrm{~nm}$, respectively for $\mathbf{1}$, suggests that the $\mathrm{S}_{0} \rightarrow{ }^{3}$ MLCT transition is greatly enhanced and becomes partially allowed due to strong spin-orbit coupling. Complex 1 exhibits an intense emission with a maximum at $607 \mathrm{~nm}(\Phi=0.52)$ and a lifetime as short as $1.05 \mu \mathrm{s}$ in degassed $\mathrm{CH}_{2} \mathrm{Cl}_{2}$. An oxygen quenching rate of $\approx 1.78 \times 10^{9} \mathrm{M}^{-1} \mathrm{~s}^{-1}$ for the emission in $\mathrm{CH}_{2} \mathrm{Cl}_{2}$, together with its spectral overlap with respect to the ${ }^{3}$ MLCT absorption profile, leads us to conclude that the emission originates from a triplet manifold.
The phosphorescence peak wavelength can be fine-tuned by replacing the auxiliary group. Substituting the $\mathrm{CF}_{3}$ in $\mathbf{1}$ with the electron-donating $t$-butyl group, yielding complex $\mathbf{2}$, gives rise to a bathochromic spectral shift due to the destabilization of the d-orbital in the central Ir $^{\mathrm{III}}$ atom. Conversely, the (2-pyridyl) triazolate in $\mathbf{3}$ serves as a stronger electron-withdrawing ligand, stabilizing the d-orbital and giving rise to an emission $\approx 10 \mathrm{~nm}$ hypsochromically shifted relative to that of $\mathbf{1}$. In the solid crystal, the emission spectra of both $\mathbf{1}$ and $\mathbf{3}$ are bathochromically shifted relative to the solution spectra. This phenomenon is generally attributed to $\pi-\pi$ stacking between ligand chromophores; such packing has been observed in the crystal structure of $\mathbf{1}$. On the other hand, as indicated by the small shift in wavelength (see Table 1), the $\pi-\pi$ stacking of 2 is supposed to be less significant. We assume that an increase in the steric hindrance via the introduction of a bulky $t$-butyl group in $\mathbf{2}$ reduces the stacking effect drastically, resulting in a spectral resemblance between the solution and solid phases. Detailed photoluminescent and dynamical properties for complexes $\mathbf{1}-\mathbf{3}$ are listed in Table 1.

Table 1. Photophysical properties of complexes 1-3.

\begin{tabular}{cccccc}
\hline Complex & $\begin{array}{c}\lambda_{\max }^{\text {abs }} \\
{[\mathrm{nm}]}\end{array}$ & $\begin{array}{c}\varepsilon \\
{\left[\mathrm{M}^{-1} \mathrm{~cm}^{-1}\right]}\end{array}$ & $\begin{array}{c}P L \lambda_{\max }[\mathrm{a}] \\
{[\mathrm{nm}]}\end{array}$ & $\begin{array}{c}\Phi[\mathrm{a}] \\
\text { degassed }\end{array}$ & $\begin{array}{c}\tau[\mathrm{a}] \\
{[\mu \mathrm{s}]}\end{array}$ \\
\hline $\mathbf{1}$ & 565 & 1330 & $607(634)$ & 0.52 & 1.05 \\
& 525 & 2150 & & $(0.41)$ & $(0.40)$ \\
& 470 & 3970 & & & \\
$\mathbf{2}$ & 575 & 1369 & $638(638)$ & 0.27 & 0.92 \\
& 530 & 2120 & & $(0.17)$ & $(0.24)$ \\
& 475 & 4670 & & & \\
& & & & & \\
& 556 & 933 & $596(625)$ & 0.61 & 1.11 \\
& 523 & 1720 & & $(0.32)$ & $(0.35)$ \\
& 468 & 2670 & & & \\
\hline
\end{tabular}

[a] In $\mathrm{CH}_{2} \mathrm{Cl}_{2}$. Data in parentheses refer to the solid state.

\subsection{OLED Characterization}

Considering the long-wavelength emission required for red phosphors, both complexes $\mathbf{1}$ and $\mathbf{2}$ were chosen for the fabrication of OLED devices (Table 2). Of particular note is that devices I-III became brighter and more efficient as the doping level of $\mathbf{1}$ was increased from $\approx 7-21 \%$. To our knowledge, this is in contrast to most literature reports, in which an upper limit of the doping level of $\approx 10 \%$ is given, except for the case where the pinene group was introduced to suppress aggregation quenching. ${ }^{[13]}$ The unexpected success at high doping levels prompted us to adopt a non-doped, host-emitting approach in the fabrication of the fourth device (IV in Table 2). Whereas devices I-III showed unsatisfactory orange-red EL, device IV clearly showed a deep-red EL with $\lambda_{\max }$ at $626 \mathrm{~nm}$ (Fig. 4) corresponding to $(0.66,0.34)$ of the 1931 Commission Internationale de l'Eclairage (CIE) chromaticity (Table 2).

The performance of this authentic red, non-doped OLED is remarkable, considering that a sufficient luminance 
Table 2. EL characteristics of OLEDs (devices I-VIII) fabricated using complex 1 or 2.

\begin{tabular}{|c|c|c|c|c|c|}
\hline $\begin{array}{l}\text { Device } \\
\text { [a] }\end{array}$ & $\begin{array}{l}\text { Max. luminance } \\
{\left[\mathrm{cd} \mathrm{m}^{-2}\right][\mathrm{b}]}\end{array}$ & $\begin{array}{c}\text { Efficiency } \\
{[\%][c]}\end{array}$ & $\begin{array}{c}\text { Max. efficiency } \\
{\left[\%, \mathrm{~cd} \mathrm{~A}^{-1}, \operatorname{Im~} \mathrm{W}^{-1}\right]}\end{array}$ & $\begin{array}{c}\mathrm{EL} \lambda_{\max } \\
{[\mathrm{nm}]}\end{array}$ & $\begin{array}{l}\mathrm{CIE} \\
{[x, y]}\end{array}$ \\
\hline \multirow[t]{2}{*}{1} & 58570 & $6.8(12)$ & $8.0,16.4,5.9$ & 600 & $0.59,0.39$ \\
\hline & $(14010,3160)$ & $7.7(10)$ & & & \\
\hline \multirow[t]{2}{*}{ II } & 45200 & 7.1 (12) & $8.1,14.0,4.9$ & 606 & $0.62,0.37$ \\
\hline & $(12370,2840)$ & $8.1(10)$ & & & \\
\hline \multirow[t]{2}{*}{ III } & 38180 & $7.3(12)$ & $8.8,14.5,5.0$ & 610 & $0.63,0.37$ \\
\hline & $(11990,2870)$ & $8.7(10)$ & & & \\
\hline \multirow[t]{2}{*}{ IV } & 29790 & $5.5(10)$ & $6.3,6.7,2.7$ & 626 & $0.66,0.34$ \\
\hline & $(5780,1330)$ & $6.3(8)$ & & & \\
\hline \multirow[t]{2}{*}{ v } & 39260 & $7.3(12)$ & $8.1,13.0,4.1$ & 618 & $0.62,0.34$ \\
\hline & $(11560,2590)$ & $8.1(10)$ & & & \\
\hline \multirow[t]{2}{*}{$\mathrm{VI}$} & 40410 & $6.3(12)$ & $7.6,11.2,4.4$ & 622 & $0.63,0.34$ \\
\hline & $(9360,2190)$ & $7.4(9)$ & & & \\
\hline \multirow[t]{2}{*}{ VII } & 31450 & $5.2(11)$ & $5.2,7.3,2.2$ & 622 & $0.63,0.34$ \\
\hline & $(7283,878)$ & $3.1(8)$ & & & \\
\hline \multirow[t]{2}{*}{ VIII } & 6381 & 2.5 (11) & $2.7,1.4,0.4$ & 652 & $0.69,0.31$ \\
\hline & $(1272,270)$ & $2.6(10)$ & & & \\
\hline
\end{tabular}

[a] Devices I-IV: ITO/NPB $(40 \mathrm{~nm}) / 1: \mathrm{CBP}(x \%, 30 \mathrm{~nm}) / \mathrm{BCP}(10 \mathrm{~nm}) / \mathrm{Alq}_{3}$ $(30 \mathrm{~nm}) / \mathrm{Mg}: \mathrm{Ag}, x=7,14,21,100 \%$, respectively. Devices V-VIII: ITO/ $\mathrm{NPB}(40 \mathrm{~nm}) / 2: \mathrm{CBP}(x \%, 30 \mathrm{~nm}) / \mathrm{BCP}(10 \mathrm{~nm}) / \mathrm{Alq}_{3}(30 \mathrm{~nm}) / \mathrm{Mg}: \mathrm{Ag}, x=7$, $14,21,100 \%$, respectively. [b] Numbers in parentheses are the electroluminance at current densities of 100 and $20 \mathrm{~mA} \mathrm{~cm}^{-2}$. [c] External quantum efficiency at current densities of 100 and $20 \mathrm{~mA} \mathrm{~cm}^{-2}$. Numbers in parentheses are the corresponding voltage.

$\left(1330 \mathrm{~cd} \mathrm{~m}^{-2}\right)$ and good efficiency $\left(6.3 \%, 6.7 \mathrm{~cd} \mathrm{~A}^{-1}\right.$, or $2.5 \mathrm{~lm} \mathrm{~W}^{-1}$ ) were successfully achieved at a practical current density of $20 \mathrm{~mA} \mathrm{~cm}^{-2}$. Based on the same protocol, another red OLED, containing phosphor 2 (device VIII in Table 2), was also fabricated; this showed an even further red-shifted EL with $\lambda_{\max }$ at $652 \mathrm{~nm}$, corresponding to $(0.69,0.31)$ CIE coordinates. The brightness and efficiency of device VIII were moderately reduced, and the turn-on voltage was relatively higher than those of device IV (see Fig. 4). In addition to the reason of low quantum efficiency, a smaller bandgap (higher energy level of highest occupied molecular orbital (HOMO) or lower energy level of lowest occupied molecular orbital (LUMO)), and hence a stronger charge trap of $\mathbf{2}$ may be the cause for the different performances. The results here successfully demonstrate unusual phosphorescence-based red OLEDs fabricated using a non-doped architecture, and the devices were bright and efficient. ${ }^{[6]}$ Moreover, in comparison with other red OLEDs based on Ir-complex dopants, ${ }^{[14]}$ devices I-IV suffered less from a decay in efficiency at an elevated current density (Fig. 4). In particular, it is noteworthy that the non-doped device VIII showed quite a stable efficiency over a wide range of current density, up to $500 \mathrm{~mA} \mathrm{~cm}^{-2}$. Such an extraordinary performance can be attributed to the relatively short emission lifetimes of complexes $\mathbf{1}$ and $\mathbf{2}$. a)

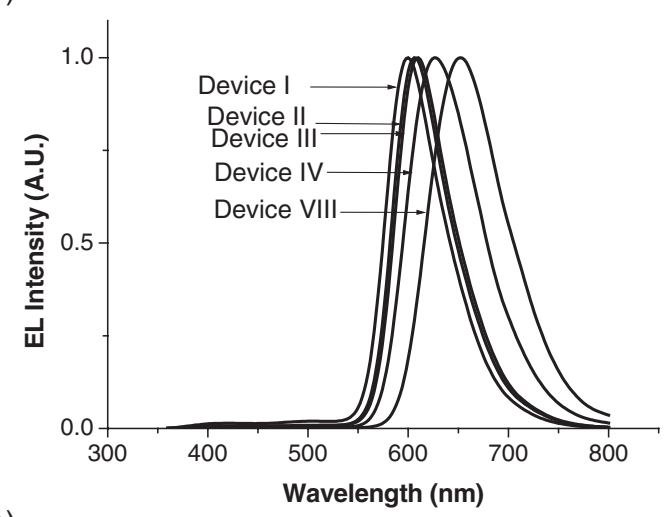

b)

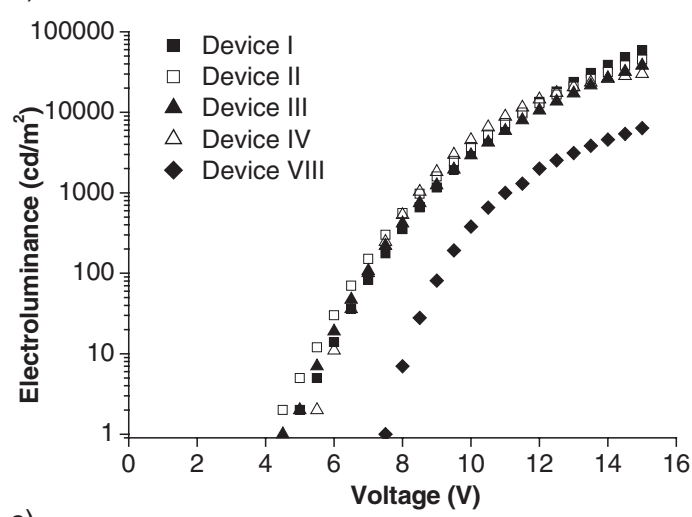

c)

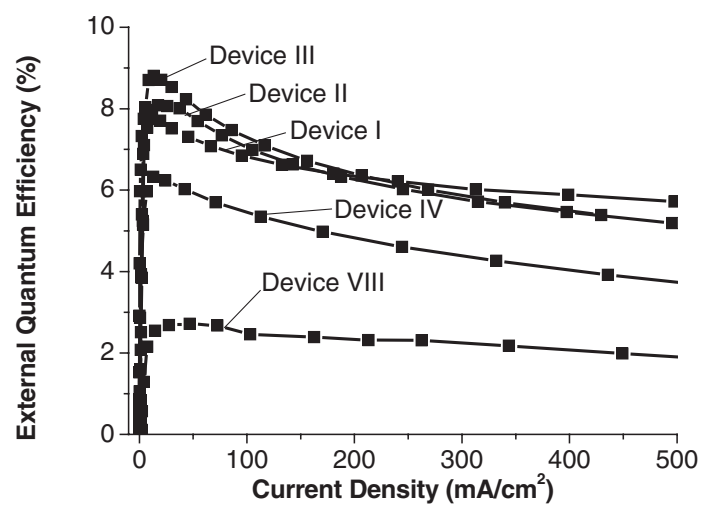

Figure 4. EL spectra (a), voltage dependency of electroluminescence (b), and current-density dependency of external quantum efficiency (c) of OLED devices I, II, III, IV, and VIII.

\section{Conclusion}

We have demonstrated the synthesis of novel, red-emitting $\mathrm{Ir}^{\mathrm{III}}$ complexes based on the 4-phenyl quinazoline and (2-pyridyl) pyrazole ligands. In contrast to most other Ir $^{\mathrm{III}}$ emitters, this new series of complexes can be fabricated using a nondoped OLED structure, even though $\pi-\pi$ stacking among the ligand chromophores is obviously present between neighboring molecules, as revealed by X-ray structure analysis. Moreover, the complexes in this series have high phosphorescence yields 
(see Table 1) with relatively short lifetimes of $<1 \mu$ s, which are significantly shorter than those of other known red phosphorescence emitters, such as platinum octaethylporphyrin $(\mathrm{Pt}(\mathrm{OEP}))(\approx 50 \mu \mathrm{s}), \operatorname{Ir}(\mathrm{btp})_{2}$ (acac) $(4 \mu \mathrm{s}),{ }^{[15]}$ and $\operatorname{Ir}(\mathrm{piq})_{2}$ (acac) $(1.7 \mu \mathrm{s}),{ }^{[14]}$ and comparable with that of the best performing $\operatorname{Ir}(\text { tiq })_{3}$ and $\operatorname{Ir}(\text { fliq })_{3}(0.74 \mu$ s) complexes (btp: 2-(2'-benzo[4,5$\alpha$ ]thienyl)pyridinato; piq: 1-(phenyl)isoquinolinato; tiq: 1-thiophen-2-ylisoquinolinato; fliq: 1-(9,9-dimethyl-9H-fluoren-2yl)isoquinolinato). ${ }^{[1]}$ We believe that the short radiative lifetime is pivotal for rationalizing the unusually strong phosphorescence from this simplified device structure. Our finding is of particular importance for fabricating devices with a much simpler, more cost-effective architecture. Based on a similar argument, this non-doped device architecture should be equally applicable to other phosphorescent emitters, so long as the guest emitters possess a similar degree of intermolecular $\pi-\pi$ stacking as well as an extraordinarily short radiative lifetime in the solid state. Focus on generalizing this proposed mechanism via the design and synthesis of other phosphorescent host-emitter materials is currently in progress.

\section{Experimental}

General Information: All reactions were performed under nitrogen. Solvents were distilled from an appropriate drying agent prior to use. Commercially available reagents were used without further purification. Mass spectra were obtained on a JEOL SX-102A instrument operating in electron impact (EI) mode or fast atom bombardment (FAB) mode. ${ }^{1} \mathrm{H}$ and ${ }^{13} \mathrm{C}$ NMR spectra were recorded on Varian Mercury-400 or INOVA-500 instruments.

Cyclometallated Ir III Dimer: The chloride-bridged $\mathrm{Ir}^{\mathrm{III}}$ dimer complex with formula $\left[(\text { nazo })_{2} \mathrm{IrCl}\right]_{2}$ was synthesized according to the method reported by Nonoyama [16], which involving refluxing $\mathrm{IrCl}_{3}$. $n \mathrm{H}_{2} \mathrm{O}(3.02 \mathrm{~g}, 8.5 \mathrm{mmol})$ with 4-phenylquinazoline (nazo) $\mathrm{H}(4.04 \mathrm{~g}$, $19.6 \mathrm{mmol})$ in a mixture of 2-methoxyethanol $(30 \mathrm{~mL})$ and water $(10 \mathrm{~mL})$ for $24 \mathrm{~h}$. The red product $(4.98 \mathrm{~g}, 3.9 \mathrm{mmol}, 92 \%)$ was isolated by filtration, washed with cold acetone, and dried under vacuum.

Spectral Data: ${ }^{1} \mathrm{H}$ NMR $\left(500 \mathrm{MHz}, \mathrm{CDCl}_{3}, 294 \mathrm{~K}\right) \delta[\mathrm{ppm}]: 9.58$ $(\mathrm{s}, 4 \mathrm{H}, \mathrm{CH}), 8.89(\mathrm{~d}, J=8.5 \mathrm{~Hz}, 4 \mathrm{H}, \mathrm{CH}), 8.26(\mathrm{~d}, J=8.0 \mathrm{~Hz}, 4 \mathrm{H}, \mathrm{CH})$ $\approx 8.07-8.02(\mathrm{~m}, 8 \mathrm{H}, \mathrm{CH}), \approx 7.86-7.83(\mathrm{~m}, 4 \mathrm{H}, \mathrm{CH}), 6.88(\mathrm{t}, J=7.3 \mathrm{~Hz}$, $4 \mathrm{H}, \mathrm{CH}), 6.59(\mathrm{t}, J=7.3 \mathrm{~Hz}, 4 \mathrm{H}, \mathrm{CH}), 6.13(\mathrm{~d}, J=8.0 \mathrm{~Hz}, 4 \mathrm{H}, \mathrm{CH})$.

Preparation of $\left[(\text { nazo })_{2} \operatorname{Ir}(F p p z)\right]$ : To a $100 \mathrm{~mL}$ flask was added $\left[(\text { nazo })_{2} \mathrm{IrCl}\right]_{2} \quad(1.04 \mathrm{~g}, \quad 0.815 \mathrm{mmol}), 3$-trifluoromethyl-5-(2-pyridyl) pyrazole (FppzH, $0.42 \mathrm{~g}, 1.97 \mathrm{mmol}), \mathrm{Na}_{2} \mathrm{CO}_{3}(0.86 \mathrm{~g}, 8.15 \mathrm{mmol})$, and 2-ethoxyethanol $(40 \mathrm{~mL})$, and the mixture was then heated to reflux for $8 \mathrm{~h}$. Excess water was added after cooling the solution to room temperature. The resulting precipitate was collected by filtration and washed with diethyl ether. Further purification was conducted using silica gel column chromatography using $\mathrm{CH}_{2} \mathrm{Cl}_{2}$ as the eluent, giving $1.16 \mathrm{~g}$ of red-orange solid $(\mathbf{1}, 1.42 \mathrm{mmol}, 87 \%)$. A single crystal suitable for X-ray diffraction was obtained from a layered solution of methanol and $\mathrm{CH}_{2} \mathrm{Cl}_{2}$

Spectral Data of 1: MS (EI), $m / z=815, \mathrm{M}^{+} .{ }^{1} \mathrm{H}$ NMR $(500 \mathrm{MHz}$ $\left.\mathrm{CDCl}_{3}, 294 \mathrm{~K}\right) \delta[\mathrm{ppm}]: 8.97(\mathrm{~d}, J=8.5 \mathrm{~Hz}, 1 \mathrm{H}, \mathrm{CH}), 8.83(\mathrm{~d}, J=8.5 \mathrm{~Hz}$, $1 \mathrm{H}, \mathrm{CH}), 8.45(\mathrm{~d}, J=8.0 \mathrm{~Hz}, 1 \mathrm{H}, \mathrm{CH}), 8.36(\mathrm{~d}, J=8.0 \mathrm{~Hz}, 1 \mathrm{H}, \mathrm{CH})$ $8.32(\mathrm{~s}, 1 \mathrm{H}, \mathrm{CH}), 8.22(\mathrm{~s}, 1 \mathrm{H}, \mathrm{CH}), 8.08(\mathrm{~d}, J=7.5 \mathrm{~Hz}, 1 \mathrm{H}, \mathrm{CH}), 8.03$ $(\mathrm{d}, J=8.5 \mathrm{~Hz}, 1 \mathrm{H}, \mathrm{CH}), \approx 7.93-7.88(\mathrm{~m}, 3 \mathrm{H}, \mathrm{CH}), \approx 7.82-7.77(\mathrm{~m}, 3 \mathrm{H}$, $\mathrm{CH}), 7.58(\mathrm{~d}, J=5.5 \mathrm{~Hz}, 1 \mathrm{H}, \mathrm{CH}), \approx 7.14-7.09(\mathrm{~m}, 4 \mathrm{H}, \mathrm{CH}), 6.95$ $(\mathrm{t}, J=7.0 \mathrm{~Hz}, 1 \mathrm{H}, \mathrm{CH}), 6.86(\mathrm{t}, J=7.0 \mathrm{~Hz}, 1 \mathrm{H}, \mathrm{CH}), 6.51(\mathrm{~d}, J=7.5 \mathrm{~Hz}$, $1 \mathrm{H}, \mathrm{CH}), 6.44(\mathrm{~d}, J=7.0 \mathrm{~Hz}, 1 \mathrm{H}, \mathrm{CH}) .{ }^{19} \mathrm{~F}$ NMR $\left(470 \mathrm{MHz} \mathrm{CDCl}_{3}\right)$ $\delta$ [ppm]: -60.0 (s). Anal. calcd. for $\mathrm{C}_{37} \mathrm{H}_{23} \mathrm{~F}_{3} \mathrm{IrN}_{7}$ : N, 12.03; C, 54.54; H, 2.85. Found: N, 11.91; C, 54.22; H, 3.23 .
$X$-ray Structural Analysis: Single crystal X-ray diffraction data were measured on a Bruker Smart charge-coupled device (CCD) diffractometer using $\lambda(\mathrm{MoK} \alpha)$ radiation $(\lambda=0.71073 \AA)$. The data collection was executed using the SMART program. Cell refinement and data reduction were made with the SAINT program. The structure was determined using the SHELXTL/PC program and refined using full-matrix least squares. All non-hydrogen atoms were refined anisotropically, whereas hydrogen atoms were placed at the calculated positions and included in the final stage of refinements with fixed parameters.

Selected Crystal Data of 1: $\mathrm{C}_{37} \mathrm{H}_{23} \mathrm{~F}_{3} \mathrm{~N}_{7} \mathrm{Ir} \cdot \mathrm{CH}_{4} \mathrm{O}, M=846.87$, monoclinic, space group $P 2_{1} / n, a=14.5269(7), b=13.2230(6), c=17.0248(8) \AA$ $\beta=94.9691(11)^{\circ}, V=3258.0(3) \AA^{3}, Z=4, \rho_{\text {alcdc }}=1.727 \mathrm{~g} \mathrm{~cm}^{-1}, F(000)=$ 1664, crystal size $=0.40 \leftrightarrow 0.03 \leftrightarrow 0.02 \mathrm{~mm}, \quad \lambda(\operatorname{MoK} \alpha)=0.7107 \AA$, $T=295(2) \mathrm{K}, \mu=4.159 \mathrm{~mm}^{-1}, 7475$ reflections collected $\left(R_{\text {int }}=0.0606\right)$, final $R_{1}[I>2 \sigma(I)]=0.0376$, and $w R_{2}$ (all data) $=0.0873$. The crystallographic data of this complex (excluding structure factors) have been deposited at the Cambridge Crystallographic Data Centre with the allocated deposition number CCDC-238210.

Preparation of $\left[(\text { nazo })_{2} \operatorname{Ir}(\right.$ Bppz $\left.)\right]$ : A mixture of $\left[(\text { nazo })_{2} \mathrm{IrCl}\right]_{2}$ $(1.00 \mathrm{~g}, 0.784 \mathrm{mmol}), 3-t$-butyl-5-(2-pyridyl) pyrazole $(\mathrm{BppzH}, 0.40 \mathrm{~g}$, $1.96 \mathrm{mmol}), \quad \mathrm{Na}_{2} \mathrm{CO}_{3}(0.82 \mathrm{~g}, \quad 7.74 \mathrm{mmol})$, and 2-ethoxyethanol $(40 \mathrm{~mL})$ was heated to reflux for $8 \mathrm{~h}$. Excess water was added after cooling the solution to room temperature. The resulting precipitate was collected by filtration and washed with diethyl ether. Further purification was conducted by direct vacuum sublimation $\left(280^{\circ} \mathrm{C}, 160 \mathrm{mtorr}\right)$, giving $1.00 \mathrm{~g}$ of dark-red solid $(\mathbf{2}, 1.25 \mathrm{mmol}, 79 \%)$.

Spectral Data of 2: MS (FAB), $\mathrm{m} / \mathrm{z} \quad 804,(\mathrm{M}+1)^{+} .{ }^{1} \mathrm{H}$ NMR $\left(400 \mathrm{MHz}, \mathrm{CDCl}_{3}, 294 \mathrm{~K}\right) \delta[\mathrm{ppm}]: 8.96(\mathrm{~d}, J=8.8 \mathrm{~Hz}, 1 \mathrm{H}, \mathrm{CH}), 8.82$ $(\mathrm{d}, J=8.8 \mathrm{~Hz}, 1 \mathrm{H}, \mathrm{CH}), 8.46(\mathrm{~d}, J=8.0 \mathrm{~Hz}, 1 \mathrm{H}, \mathrm{CH}), 8.33(\mathrm{~d}, J=8.0 \mathrm{~Hz}$, $1 \mathrm{H}, \mathrm{CH}), 8.28(\mathrm{~s}, 1 \mathrm{H}, \mathrm{CH}), 8.18(\mathrm{~s}, 1 \mathrm{H}, \mathrm{CH}), 8.06(\mathrm{~d}, J=8.4 \mathrm{~Hz}, 1 \mathrm{H}$, $\mathrm{CH}), 8.01(\mathrm{~d}, J=8.4 \mathrm{~Hz}, 1 \mathrm{H}, \mathrm{CH}) \approx 7.91-7.85(\mathrm{~m}, 2 \mathrm{H}, \mathrm{CH}) \approx 7.83-7.70$ $(\mathrm{m}, 4 \mathrm{H}, \mathrm{CH}), 7.50(\mathrm{~d}, J=5.2 \mathrm{~Hz}, 1 \mathrm{H}, \mathrm{CH}), 7.14(\mathrm{t}, J=8.0 \mathrm{~Hz}, 1 \mathrm{H}, \mathrm{CH})$ $7.09(\mathrm{t}, J=8.0 \mathrm{~Hz}, 1 \mathrm{H}, \mathrm{CH}), \approx 6.95-6.90(\mathrm{~m}, 3 \mathrm{H}, \mathrm{CH}), 6.57(\mathrm{~s}, 1 \mathrm{H}, \mathrm{CH})$, $6.51(\mathrm{t}, J=7.6 \mathrm{~Hz}, 2 \mathrm{H}, \mathrm{CH}), 1.26\left(\mathrm{~s}, 9 \mathrm{H}, \mathrm{CMe}_{3}\right)$. Anal. calcd. for $\mathrm{C}_{40} \mathrm{H}_{32} \mathrm{IrN}_{7}: \mathrm{N}, 12.21 ; \mathrm{C}, 59.83 ; \mathrm{H}, 4.02$. Found: $\mathrm{N}, 12.15 ; \mathrm{C}, 59.56$; $\mathrm{H}, 4.23$.

Preparation of $\left[(\text { nazo })_{2} \operatorname{Ir}(\mathrm{Fptz})\right]$ : To a $100 \mathrm{~mL}$ flask was added $\left[(\text { nazo })_{2} \mathrm{IrCl}\right]_{2} \quad(0.20 \mathrm{~g}, \quad 0.157 \mathrm{mmol}), \quad 3$-trifluoromethyl-5-(2-pyridyl) triazole (FptzH, $0.08 \mathrm{~g}, 0.392 \mathrm{mmol}), \mathrm{Na}_{2} \mathrm{CO}_{3}(0.17 \mathrm{~g}, 1.57 \mathrm{mmol})$, and 2-ethoxyethanol $(40 \mathrm{~mL})$, and the mixture was then heated to reflux for $9 \mathrm{~h}$. Excess water was added after cooling the solution to room temperature. The resulting precipitate was collected by filtration and washed with diethyl ether. Further purification was conducted using silica gel column chromatography using $\mathrm{CH}_{2} \mathrm{Cl}_{2}$ as the eluent, giving $210 \mathrm{mg}$ of orange solid $(\mathbf{3}, 0.260 \mathrm{mmol}, 82 \%)$.

Spectral Data of 3: MS (FAB), $\mathrm{m} / z$ 817, $(\mathrm{M}+1)^{+} .{ }^{1} \mathrm{H}$ NMR $\left(500 \mathrm{MHz}, \mathrm{CDCl}_{3}, 294 \mathrm{~K}\right) \delta[\mathrm{ppm}]: 8.88(\mathrm{~d}, J=8.5 \mathrm{~Hz}, 1 \mathrm{H}, \mathrm{CH}), 8.84$ $(\mathrm{d}, J=8.5 \mathrm{~Hz}, 1 \mathrm{H}, \mathrm{CH}), 8.47(\mathrm{~s}, 1 \mathrm{H}, \mathrm{CH}), 8.38(\mathrm{dd}, J=9.0 \mathrm{~Hz}, 5.5 \mathrm{~Hz}$ $2 \mathrm{H}, \mathrm{CH}), 8.31(\mathrm{~d}, J=7.5 \mathrm{~Hz}, 1 \mathrm{H}, \mathrm{CH}), 8.21(\mathrm{~s}, 1 \mathrm{H}, \mathrm{CH}), 8.08$ $(\mathrm{d}, J=8.0 \mathrm{~Hz}, 1 \mathrm{H}, \mathrm{CH}), 8.02(\mathrm{~d}, J=9.0 \mathrm{~Hz}, 1 \mathrm{H}, \mathrm{CH}), \approx 7.92-7.87$ $(\mathrm{m}, 2 \mathrm{H}, \mathrm{CH}), \approx 7.86-7.82(\mathrm{~m}, 1 \mathrm{H}, \mathrm{CH}), \approx 7.79-7.75(\mathrm{~m}, 2 \mathrm{H}, \mathrm{CH}), 7.57$ $(\mathrm{d}, J=5.5 \mathrm{~Hz}, 1 \mathrm{H}, \mathrm{CH}) \approx 7.15-7.11(\mathrm{~m}, 2 \mathrm{H}, \mathrm{CH}), 7.46(\mathrm{t}, J=7.0 \mathrm{~Hz}, 1 \mathrm{H}$, $\mathrm{CH}), 6.96(\mathrm{t}, J=7.0 \mathrm{~Hz}, 1 \mathrm{H}, \mathrm{CH}), 6.86(\mathrm{t}, J=7.0 \mathrm{~Hz}, 1 \mathrm{H}, \mathrm{CH}), 6.57$ $(\mathrm{d}, J=8.0 \mathrm{~Hz}, 1 \mathrm{H}, \mathrm{CH}), 6.47(\mathrm{~d}, J=8.0 \mathrm{~Hz}, 1 \mathrm{H}, \mathrm{CH})$ Anal. calcd. for $\mathrm{C}_{36} \mathrm{H}_{22} \mathrm{~F}_{3} \mathrm{IrN}_{8}$ : N, 13.74; C, 53.00; H, 2.72 Found: N, 13.60; C, 53.21; $\mathrm{H}, 2.91$.

Spectroscopic and Dynamic Measurements: Steady-state absorption and emission spectra were recorded using a Hitachi (U-3310) spectrophotometer and an Edinburgh (FS920) fluorimeter, respectively. A configuration of front-face excitation was used to measure the emission of the solid sample, in which the cell was made by assembling two edge-polished quartz plates with various Teflon spacers. Lifetime studies were performed using an Edinburgh FL 900 photon-counting system with a hydrogen-filled/or a nitrogen lamp as the excitation source. An integrating sphere (Labsphere) was applied to measure the quantum yield in the solid state, in which the solid sample film was prepared via the vapor-deposition method and was excited by a $514 \mathrm{~nm}$ $\mathrm{Ar}^{+}$laser line. The resulting luminescence was acquired by an intensified charge-coupled detector for subsequent quantum yield analyses. 
OLED Fabrication and Measurement: The fabrication of OLEDs was conducted using high-vacuum $\left(10^{-6}\right.$ torr $)$ thermal evaporation of the material onto pre-cleaned indium tin oxide (ITO)-coated glass substrates (sheet resistance $\leq 50 \Omega / \mathrm{sq}$ ). NPB, CBP, BCP, and $\mathrm{Alq}_{3}$ are abbreviations for 1,4-bis(1-naphylphenylamino) biphenyl, 1,4-bis(N-carbazolyl) biphenyl, 1,4-bis(1-naphylphenylamino) biphenyl, 2,9-dimethyl-4,7-diphenyl-1,10-phenanthroline, and tris(8-hydroxyquinoline) aluminum, respectively. EL characteristics, including electroluminance $\left[\mathrm{cd} \mathrm{m}^{-2}\right]$, current density $\left[\mathrm{mA} \mathrm{cm}^{-2}\right]$, driving voltage [V], and EL quantum efficiency [\%], [cd A $\left.\mathrm{cd}^{-1}\right]$, and $\left[\operatorname{lm~} \mathrm{W}^{-1}\right]$, were recorded using literature methods [17].

Received: March 31, 2004 Final version: May 14, 2004

[1] a) M. A. Baldo, D. F. O’Brien, Y. You, A. Shoustikov, S. Sibley, M. E. Thompson, S. R. Forrest, Nature 1998, 395, 151. b) M. K. Nazeeruddin, R. Humphry-Baker, D. Berner, S. Rivier, L. Zuppiroli, M. Graetzel, J. Am. Chem. Soc. 2003, 125, 8790. c) A. J. Middleton, W. J. Marshall, N. S. Radu, J. Am. Chem. Soc. 2003, 125, 880. d) X. Gong, J. C. Ostrowski, G. C. Bazan, D. Moses, A. J. Heeger, M. S. Liu, A. K.-Y. Jen, Adv. Mater. 2003, 15, 45.

[2] a) B. Carlson, G. D. Phelan, W. Kaminsky, L. Dalton, X. Z. Jiang, S. Liu, A. K.-Y. Jen, J. Am. Chem. Soc. 2002, 124, 14162. b) J. C. Ostrowski, M. R. Robinson, A. J. Heeger, G. C. Bazan, Chem. Commun. 2002, 784. c) J.-P. Duan, P.-P. Sun, C.-H. Cheng, Adv. Mater. 2003, 15,224 . d) T. Tsuzuki, N. Shirasawa, T. Suzuki, S. Tokito, $A d v$ Mater. 2003, 15, 1455

[3] a) V. V. Grushin, N. Herron, D. D. Le Cloux, W. J. Marshall, V. A Petrov, Y. Wang, Chem. Commun. 2001, 1494. b) A. B. Tamayo, B. D. Alleyne, P. I. Djurovich, S. Lamansky, I. Tsyba, N. N. Ho, R. Bau, M. E. Thompson, J. Am. Chem. Soc. 2003, 125, 7377 .

[4] a) H. Kanai, Ichinosawa, Y. Sato, Synth. Met. 1997, 91, 195. b) C. Adachi, R. Kwong, S. R. Forrest, Org. Electron. 2001, 2, 37. c) S. Lamansky, P. I. Djurovich, F. Abdel-Razzaq, S. Garon, D. L. Murphy, M. E. Thompson, J. Appl. Phys. 2002, 92, 1570. d) S. Tokito, T. Iijima,
Y. Suzuri, H. Kita, T. Tsuzuki, F. Sato, Appl. Phys. Lett. 2003, 83, 569.

[5] a) Y. Wang, N. Herron, V. V. Grushin, D. Le Cloux, V. Petrov, Appl. Phys. Lett. 2001, 79, 449. b) R. J. Holmes, B. W. D'Andrade, S. R Forrest, X. Ren, J. Li, M. E. Thompson, Appl. Phys. Lett. 2003, 83, 3818.

[6] V. Grushin, D. D. Lecloux, V. A. Petrov, Y. Wang, US Patent $6670645,2003$.

[7] a) H.-C. Yeh, L.-H. Chan, W.-C. Wu, C.-T. Chen, J. Mater. Chem 2004, 14, 1240. b) K. R. J. Thomas, J. T. Lin, M. Velusamy, Y.-T. Tao, C.-H. Chuen, Adv. Funct. Mater. 2004, 14, 83. c) H.-C. Yeh, S.-J. Yeh, C.-T. Chen, Chem. Commun. 2003, 2632. d) W.-C. Wu, H.-C. Yeh, L.-H. Chan, C.-T. Chen, Adv. Mater. 2002, 14, 1072. e) K. R. Justin Thomas, J. T. Lin, Y.-T. Tao, C.-H. Chuen, Adv. Mater. 2002, 14, 822.

[8] B. C. Uff, B. L. Joshi, F. D. Popp, J. Chem. Soc., Perkin Trans. 11986 , 2295.

[9] F. O. Graces, K. A. King, R. J. Watts, Inorg. Chem. 1988, 27, 3464.

[10] a) S. Lamansky, P. Djurovich, D. Murphy, F. Abdel-Razzaq, R. Kwong, I. Tsyba, M. Bortz, B. Mui, R. Bau, M. E. Thompson, Inorg. Chem. 2001, 40, 1704. b) S. Lamansky, P. Djurovich, D. Murphy, F. AbdelRazzaq, H.-E. Lee, C. Adachi, P. E. Burrows, S. R. Forrest, M. E. Thompson, J. Am. Chem. Soc. 2001, 123, 4304.

[11] A. Tsuboyama, H. Iwawaki, M. Furugori, T. Mukaide, J. Kamatani, S. Igawa, T. Moriyama, S. Miura, T. Takiguchi, S. Okada, M. Hoshino, K. Ueno, J. Am. Chem. Soc. 2003, 125, 12971.

[12] P.-C. Wu, J.-K. Yu, Y.-H. Song, Y. Chi, P. -T. Chou, S.-M. Peng, G.-H. Lee, Organometallics 2003, 22, 4938.

[13] H. Z. Xie, M. W. Liu, O. Y. Wang, X. H. Zhang, C. S. Lee, L. S Hung, S. T. Lee, P. F. Teng, H. L. Kwong, H. Zheng, C. M. Che, Adv Mater. 2001, 13, 1245.

[14] Y.-J. Su, H.-L. Huang, C.-L. Li, C.-H. Chien, Y.-T. Tao, P.-T. Chou, S. Datta, R.-S. Liu, Adv. Mater. 2003, 15, 884.

[15] M. Adachi, A. Baldo, S. R. Forrest, S. Lamanky, M. Thompson, R. C. Kwong, Appl. Phys. Lett. 2001, 78, 1622.

[16] M. Nonoyama, J. Organomet. Chem. 1975, 86, 263.

[17] L.-H. Chan, R.-H. Lee, C.-F. Hsieh, H.-C. Yeh, C.-T. Chen, J. Am. Chem. Soc. 2002, 124, 6469. 